\title{
System wynagrodzeń oparty na idei udziału pracowników w zysku - studium przypadku
}

https://doi.org/10.33141/po.2005.04.09

\section{Waldemar Rzońca}

\section{Wprowadzenie}

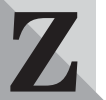

naczący rozwój zastosowań systemów wynagrodzeń wykorzystujących ideę udziału pracowników w zysku (profitsharing) zapoczątkowany został po II wojnie światowej i miał miejsce przede wszystkim w Ameryce Północnej oraz w niektórych krajach Europy Zachodniej. Mimo że w wielu państwach systemy tego typu są obecnie dość rozpowszechnione, to w Polsce - szczególnie w odniesieniu do pracowników liniowych - należą do rzadkości. W niniejszym artykule przedstawiono doświadczenia autora zebrane w trakcie opracowywania oraz wdrażania takiego systemu $\mathrm{w}$ jednym $\mathrm{z}$ wrocławskich przedsiębiorstw handlowych, działającym w branży meblowej.

\section{Idea opracowanego systemu}

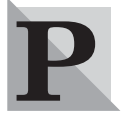

rzedsiębiorstwo będące przedmiotem zainteresowania w niniejszym artykule, zwane dalej „Spółką”, rozpoczęło swoją działalność w 1997 roku w formie spółki z ograniczoną odpowiedzialnością. Głównym przedmiotem działania Spółki w chwili jej zarejestrowania był montaż zestawów mebli kuchennych produkowanych przez inny podmiot gospodarczy zwany dalej „Fabryką”. Po kilku latach Spółka rozszerzyła swoją działalność przejmując od Fabryki punkty sprzedaży detalicznej mebli, nazywane komórkami handlowymi $(\mathrm{KH})$.

Jako jedno z pierwszych zadań w chwili przejmowania tych komórek uznano w Spółce dokonanie analizy istniejącego systemu wynagrodzeń pracowników handlowych. Analize przeprowadził zespół do spraw wynagrodzeń, którego członkiem był autor niniejszego artykułu. Zespół uznał, że na ówczesnym etapie restrukturyzacji Spółki dotychczasowy system wynagrodzeń nie był właściwy i podjął decyzję o opracowaniu nowego systemu, dla którego przyjął następujące założenia.

I. Miesięczne wynagrodzenie pracowników handlowych będzie się składać z dwóch części: z wynagrodzenia zasadniczego oraz z części ruchomej.

II. Wynagrodzenie zasadnicze powinno być na tyle wysokie, aby nie zagrażało bytowi materialnemu pracowników nawet wtedy, gdy nie otrzymają oni części ruchomej.

III. Część ruchoma wynagrodzenia powinna spełniać następujące warunki:
Przegląd Organizacji, Nr 4 (783), 2005, ss. 38-40 www.przegladorganizacji.pl Towarzystwo Naukowe Organizacji i Kierownictwa (TNOiK)
- powinna motywować pracowników do takich działań, które przyczynią się do osiągnięcia przez Spółkę jak największego wyniku finansowego, w tym do działań mających na celu obniżenie kosztów;

- zasady przyznawania części ruchomej powinny być tak określone, aby przede wszystkim nagradzać wyniki pracy zespołowej, realizowanej przez poszczególne komórki handlowe, a w ramach danej komórki motywować pracowników do indywidualnego wysiłku oraz rzetelnej i wydajnej pracy na rzecz Spółki. W szczególności zasady te powinny się przyczynić do zwiększenia rotacji zapasów mebli oraz do zmniejszenia tych zapasów, które powstawały w wyniku błędów popełnianych przez projektantów zestawów mebli kuchennych ${ }^{11}$.

Ustalono ponadto, że nowy system wynagrodzeń powinien zostać wprowadzony w życie po kilku miesiącach (3-5) od chwili przejęcia komórek handlowych. Wcześniejsze wprowadzenie uznano za niecelowe ze względu na możliwość spotęgowania się problemów, które mogły powstać w Spółce w związku z zachodzącymi zmianami strukturalnymi ${ }^{2}$.

Prace nad nowym systemem rozpoczęto od przeanalizowania asortymentowej struktury sprzedaży oraz struktury zatrudnienia w przejmowanych komórkach handlowych. Uwzględniając strukturę sprzedaży wszystkie komórki podzielono na dwie następujące grupy:

- studia kuchenne (SK), do których zaliczono wszystkie te komórki handlowe, w których prowadzono wyłącznie sprzedaż mebli kuchennych,

- salony meblowe (SM) - te komórki, w których prowadzono sprzedaż pełnego asortymentu mebli.

W dalszej części niniejszego artykułu rozważania zostaną ograniczone wyłącznie do studiów kuchennych. Ze względu na zakres obowiązków, wśród pracowników studiów wyróżniono: - kierownika studia kuchennego (niektórzy kierownicy byli jednocześnie projektantami zestawów mebli kuchennych), • projektanta-handlowca zestawów mebli kuchennych nie obciążonego wykonywaniem prac administracyjnych, zwanego dalej projektantem, $\bullet$ projektanta-handlowca zestawów mebli kuchennych, obciążonego wykonywaniem prac administracyjnych, zwanego dalej pracownikiem handlowo-administracyjnym.

Po uwzględnieniu dostępnych informacji o wysokości wynagrodzeń na podobnych stanowiskach w innych firmach handlowych, a także informacji o śred- 
niej płacy krajowej oraz o płacy minimalnej stwierdzono, że warunek II nałożony na nowy system wynagrodzeń jest spełniony. Prace zespołu skoncentrowały się zatem na poszukiwaniu odpowiednich rozwiązań w zakresie kształtowania części ruchomej wynagrodzeń. Szczególną uwagę zespół zwrócił na możliwość wykorzystania idei udziału pracowników w zysku (profitsharing), stosowanej coraz częściej w krajach europejskich oraz w USA ${ }^{3}$. W Polsce ideę profitsharingu wykorzystano między innymi przy opracowaniu systemu wynagrodzeń pracowników jednego z wrocławskich przedsiębiorstw [Rzońca, 1996]. Informacje o doświadczeniach zebranych w trakcie eksploatacji tego systemu (zwanego dalej PROWI) zostały uwzględnione w konstruowaniu zasad przyznawania części ruchomej wynagrodzeń pracownikom Spółki. Nowy system, opracowany przez zespół do spraw wynagrodzeń, nazwano PREM. Jego istotę opisano poniżej.

- Przyjęto, że ruchoma część wynagrodzeń będzie wypłacana w formie premii uznaniowej. Co miesiąc każda komórka handlowa będzie wypracowywać własna pulę pieniędzy przeznaczoną na wypłatę premii wszystkim zatrudnionym $\mathrm{w}$ niej pracownikom handlowym. Pulę tę będzie się obliczać jako pewną część miesięcznego tzw. umownego zysku brutto danej komórki (wzór 1):

$$
P R E_{i j}=W S_{i j} \times Z B R_{i j}
$$

gdzie:

$P R E_{i j}$ - pula pieniędzy przeznaczona $\mathrm{w} j$-tym miesiącu na wypłatę premii uznaniowych wszystkim pracownikom handlowym $i$-tej komórki,

$W S_{i j}$ - współczynnik określający, jaką część umownego zysku brutto $i$-tej komórki handlowej Zarzą Spółki przeznacza w $j$-tym miesiącu na wypłatę premii uznaniowych pracownikom tej komórki, $Z B R_{i j}$ - umowny zysk brutto, osiągnięty przez $i$-tą komórkę handlową w j-tym miesiącu.

Pod pojęciem umownego zysku brutto komórki handlowej będzie się rozumieć różnicę pomiędzy kwotą marży handlowej netto, wypracowanej przez tę komórkę w danym miesiącu, a przypisanymi jej kosztami. Zysk ten nazwano umownym, ponieważ przy jego obliczaniu pominięto pulę premii PRE, mimo że jest ona kosztem okresu. Uwzględnienie jej nie jest jednak możliwe, ponieważ w chwili obliczania zysku $Z B R$ jej wartość nie jest jeszcze znana. Obliczoną na podstawie wzoru 1 pulę PRE traktuje się jako ostateczną, co oznacza, że nie będzie ona miała wpływu na premie wypłacane w przyszłości ${ }^{4}$.

- Każdy z projektantów zestawów mebli kuchennych będzie uczestniczyć w podziale puli PRE wprost proporcjonalnie do wkładu, jaki wniósł w jej wypracowanie. Jako miarę tego wkładu przyjęto miesięczne przychody netto ze sprzedaży, osiagnięte przez danego projektanta. Przyznane w ten sposób premie spełniaja zatem następujący warunek:

$$
\begin{gathered}
\text { PREMIA1(1) : PREMIA1(2) }: \ldots: \\
: \text { PREMIA1 }(k)=S P(1): S P(2): \ldots: S P(k)
\end{gathered}
$$

gdzie:

PREMIA1(k) - premia przyznana w danym miesiacu $k$-temu projektantowi,

$S P(k)$ - przychody netto ze sprzedaży osiągnięte w danym miesiacu przez $k$-tego projektanta.

Celem takiego rozwiązania było umotywowanie projektantów do działań zmierzających do osiągania dużych obrotów przez studia kuchenne. Przy podziale puli premii PRE postanowiono ponadto, że - ze względów prestiżowych - kierownik studia będzie otrzymywał wyższą premię, niż każdy z podległych mu pracowników. W przypadku, gdy kierownik nie jest projektantem, wysokość premii będzie zatem obliczana według następującego wzoru:

$$
\text { PREMIA_K }=U K \times \max _{k}[P R E M I A 1(k)]
$$

gdzie:

PREMIA_K - wysokość premii przyznanej kierownikowi studia kuchennego,

UK - współczynnik, którego wartość określa Zarząd Spółki $(U K>1)$,

PREMIA1(k) - premia przyznana w danym miesiącu $k$-temu projektantowi.

Jeżeli natomiast kierownik jest projektantem, to należna mu premia będzie większa spośród dwóch następujacych wartości:

- wartości premii, która przysługuje mu jako projektantowi z tytułu osiągnięcia przez niego określonych przychodów ze sprzedaży (wzór 2),

- wartości obliczonej zgodnie ze wzorem 3 przy uwzględnieniu wszystkich projektantów, z wyjątkiem projektanta-kierownika.

Ustalono ponadto - także ze względów prestiżowych - że premia pracownika handlowo-administracyjnego zatrudnionego $\mathrm{w}$ danym studiu będzie obliczana jako określona część premii przyznanej kierownikowi tego studia (wzór 4):

$$
\text { PREMIA_AD }=U A \times P R E M I A \_K
$$

gdzie:

PREMIA_AD - premia przyznana pracownikowi handlowo-administracyjnemu,

$U A$ - współczynnik, którego wartość określa Zarząd SPÓŁKI $(U A<1)$,

PREMIA $K$ - wysokość premii przyznanej kierownikowi studia kuchennego.

Kolejną funkcją motywacyjną, którą - zgodnie z założeniami - powinien realizować nowy system wynagrodzeń było skłonienie projektantów do zmniejszenia zapasów elementów mebli kuchennych oraz sprzętu AGD, które powstawały w wyniku popełnianych przez nich błędów projektowych. Aby zrealizować tę funkcję postanowiono, że przyznaną danemu projektantowi wstępnie premię będzie się zmniejszać o wartość wprost proporcjonalną do wartości „zawinionych” przez niego zapasów.

\section{Wdrożenie systemu}

drożenie nowego systemu wynagrodzeń wymagało od Zarządu określenia wartości niektórych parametrów, a w szczególności na- 
stępujących współczynników: $W S_{i j}$ (wzór 1), UK (wzór 3) oraz UA (wzór 4). Do oszacowania wartości parametru $W S_{i j}$ wykorzystano dane historyczne z poprzedniego roku. Uwzględniając obroty każdej z komórek handlowych, osiągnięte w poszczególnych miesiącach oraz odpowiadajace tym obrotom koszty, wartości tego parametru obliczono tak, aby w skali całego roku łączna kwota premii należnych pracownikom danej komórki według nowego systemu była o kilka punktów procentowych wyższa od kwoty rzeczywiście wypłaconej, obliczonej według starego systemu. Przyjęty sposób szacowania miał na celu uwiarygodnienie nowego systemu w oczach pracowników. Wartości dwóch pozostałych parametrów ( $U K$ oraz $U A$ ) ustalono na takim poziomie, aby zachować odpowiedni prestiż kierowników komórek handlowych oraz prestiż pracowników handlowo-administracyjnych (przyjęto: $U K=1,4$ oraz $U A=0,75$ ).

Nowy system wdrożono po pięciu miesiącach od chwili przejęcia komórek handlowych. Wdrożenie go wymagało znacznego wysiłku organizacyjno-technicznego ze strony niektórych służb, a w szczególności ze strony księgowości. System ten narzucał bowiem określone wymogi dotyczące sposobu rozliczania kosztów w Spółce, przypisywania przychodów każdej z komórek handlowych oraz wymuszał dotrzymywanie ustalonych terminów spływu określonych dokumentów do działu księgowości oraz do Zarządu Spółki.

\section{Zalety i wady systemu}

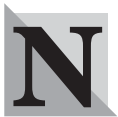

owy system stworzył Zarządowi Spółki bardzo dobre możliwości monitorowania i kontroli kosztów ponoszonych przez poszczególne komórki handlowe oraz możliwość dokonywania bieżącej oceny efektywności tych komórek. Do innych korzyści, które osiągnięto dzięki temu systemowi, należy zaliczyć:

- stworzenie w Spółce silnej motywacji do pracy zespołowej w studiach SK, poprzez fakt wypracowywania przez wszystkich pracowników danego studia wspólnej puli premii, ograniczonej od góry jedynie wypracowanym przez nich zyskiem;

- stworzenie pracownikom handlowym możliwości osiągania wysokich zarobków: w nowym systemie nie nałożono żadnych ograniczeń kwotowych ani na pulę premii przewidzianą do podziału pomiędzy pracowników danego studia, ani też na wysokość premii przyznanej konkretnemu pracownikowi;

- uświadomienie pracownikom handlowym struktury oraz wysokości kosztów ponoszonych przez każde ze studiów SK. Zainteresowanie pracowników kosztami znacznie wzrosło, ponieważ miały one bezpośredni wpływ na umowny zysk brutto komórki, a ten z kolei na ich premie. Uświadomienie to miało niebagatelne znaczenie dla postawy niektórych pracowników wobec władz Spółki: stała się ona mniej roszczeniowa (wcześniej wielu $\mathrm{z}$ nich nie uświadamiało sobie faktu istnienia niektórych kosztów, a tym bardziej nie byli świadomi ich wysokości);

- skłonienie projektantów zestawów mebli kuchennych do zmniejszenia zapasów powstałych z ich winy (zapasy elementów mebli oraz sprzętu AGD).
Główną wadą opracowanego systemu premiowania było niewystarczające motywowanie pracowników handlowych do wzmożonego wysiłku na rzecz Spółki w tych miesiącach, w których nie widzieli oni szans na wypracowanie zysku przez ich komórki. Do słabych stron nowego systemu należy zaliczyć także fakt, że nie spełnił on wszystkich oczekiwań Zarządu, dotyczących redukcji kosztów (najprawdopodobniej było to konsekwencją przemyślanych decyzji kierowników komórek KH, którzy wybrali rozwiązania finansowo korzystniejsze dla siebie). Na zakończenie warto podkreślić, że zaprezentowana w tym artykule modyfikacja koncepcji udziału pracowników w zysku, polegająca na uwzględnieniu - zamiast rzeczywistego zysku tzw. umownego zysku brutto (wzór 1) posiada dosyć istotną zaletę, a mianowicie pozwala na zaliczenie całych dochodów pracowników, wynikających z udziału w zysku, do kosztów przedsiębiorstwa, co w przypadku klasycznej idei profitsharingu na ogół nie jest możliwe.

dr inż. Waldemar Rzońca Instytut Organizacji i Zarządzania Politechniki Wrocławskiej

\section{PRZYPISY}

1) Chodzi tutaj o zapasy tych części mebli kuchennych oraz sprzętu AGD, które zostały sprowadzone przez projektantów i nie wykorzystane w sprzedanych zestawach, wskutek źle wykonanych projektów.

2) Każde przejęcie przedsiębiorstwa lub jego części przez inny podmiot gospodarczy jest dla zatrudnionych w nim pracowników źródłem dużego stresu [S. CARTWRIGHT, C.L. COOPER, 2000, s. 50]. Negatywne konsekwencje tego stresu opisano między innymi w pracy [A. POCZTOWSKI (red.), 2004]. Jak wynika z badań opublikowanych w roku 1977 [A. ZELEZNIK, M.F.R. KETS de VRIES, J. HOWARD, 1997], na stres bardziej narażeni sa pracownicy szeregowi aniżeli menedżerowie. Ponieważ w przejmowanych przez Spółkę komórkach handlowych zdecydowaną większość stanowili pracownicy liniowi, to tym bardziej należało się liczyć z możliwością wystąpienia określonych problemów.

3) O pozytywnych doświadczeniach z takimi systemami pisze Z. Jacukowicz w pracy [Z. JACUKOWICZ, 1999], opierając się na wynikach badań amerykańskich oraz brytyjskich.

4) Jest to zasadnicza różnica $\mathrm{w}$ stosunku do wspomnianego wcześniej systemu PROWI opisanego w pracy [W. RZOŃCA, 1996]

\section{BIBLIOGRAFIA}

[1] CARTWRIGHT S., COOPER C.L., HR Know-how in Mergers and Acquisitions, Chartered Institute of Personnel and Development, London 2000.

[2] JACUKOWICZ Z., Systemy wynagrodzeń, Polska Fundacja Promocji Kadr, Poltext, Warszawa 1999.

[3] POCZTOWSKI A. (red.), Zarzadzanie zasobami ludzkimi w procesach fuzji i przejęć, Oficyna Ekonomiczna, Kraków 2004

[4] RZOŃCA W., Model prowizyjnego systemu wynagradzania pracowników - koncepcja $i$ realizacja, „Przegląd Organizacji” 1996, nr 2, s. 27-31.

[5] ZELEZNIK A., KETS de VRIES M.F.R, HOWARD J., Stress Reactions in Organizations: Syndromes, Causes and Consequences „Behavioral Science” 1997, nr 22, s. 151-162. 